\title{
Betragtninger over den danske bevægelse i Nordslesvig
}

\author{
Et foredrag
}

Af G. Japsen

P. Lauridsens grundlæggende værk om den danske bevægelse i Nordslesvig før 1848, $\bowtie D_{a}$ Sønderjylland vågnede $<$, bygger på den opfattelse, at den danske og den tyske bevægelse i Sønderjylland er to sider af samme sag. De er, skriver han, udslag af samme kulturstrøm og kan føres tilbage til samme kilde.

P. Lauridsens opfattelse er skæv. De to bevægelser hvilede oprindeligt på støtte fra helt forskellige befolkningslag, og hvad den danske bevægelse angår, blev den først efter 1880 en fuldlødig nationalbevægelse, der i nogen grad kunne parallelliseres med den tyske. Jeg håber at kunne vise dette $\mathrm{i}$ det følgende.

Den slesvigholstenske og tyske bevægelse er let at forstå. Den svarer i sin karakter og tendens til de fleste andre nationale bevægelser i Europa, den italienske, den tjekkiske og den norske, for at nævne et par eksempler. Det bærende element $\mathrm{i}$ dem alle var det pågældende lands bourgeoisi med akademikere og embedsmænd. Udtrykket for denne klasses interesser er liberalismen i videste forstand, økonomisk, politisk og kulturelt, og nationalismen - det vil først og fremmest sige bestræbelsen for at danne nationalstater - har sin plads som et afgørende våben $\mathrm{i}$ liberalismens arsenal. Hvis man tror, at nationalismen i det 19. århundrede alt efter omstændighederne kunne være knyttet til feudale kræfter, bæres oppe af absolutismen eller udgøre et almueeller arbejderrøre, har man ladet sig føre på vildspor af sekundære eller tilfældige træk. Nationalismen havde altid en borgerlig, liberalistisk sjæl.

Indsnævrer man blikket til den danske bevægelses medbejler, til slesvigholstenismen, er det iøjnefaldende, at der ikke, som P.Lauridsen 
mente, er tale om en parallellisme, der kan forfølges op gennem alle led. Slesvigholstenismen var altid ufolkelig og udemokratisk. Den var altid betænkt på, hvordan den skulle kunne holde de brede masser under kontrol, og det er ikke mærkeligt, at den allierede sig med adelen og siden bøjede sig for preusserne. I sin propaganda appellerede den derfor heller ikke til folkesjælen, skønt Herder og romantikken havde stillet de bedst tænkelige våben til tyskhedens rådighed, men nøjedes med at hverve i de snævre kredse, hvor retshistoriske deduktioner, middelalderlige adelstraktater og subtile drøftelser af fyrstelige arvegangsregler kunne forstås og gøre indtryk.

Hvis man vil sætte sig ind i den særlige situation, hvori den nordslesvigske befolkning befandt sig før 1848, er det nyttigt at lære af forholdene $\mathrm{i}$ det gamle østrig-ungarske monarki. Det var her almindeligt at dele de mange nationaliteter $\mathrm{i}$ to kategorier: de historiske og de historieløse. Den første kategori omfattede de nationaliteter, hvor både over- og underklasse talte samme sprog, og som derfor havde en national kultur og en national historie. Af større interesse er den anden kategori: de historieløse nationaliteter eller nationaliteterne uden historie. Det karakteristiske her var, at overklassen var fremmed, og at der følgelig ikke havde kunnet udvikle sig en egen national kultur. Til den første kategori regnedes $f$. eks. tyskere og ungarere, til den anden bl.a. ruthenere og tjekker.

Selv om man sikkert skal tage visse forbehold, hvis man vil anvende disse begreber på tilstanden $\mathrm{i}$ det danske monarki, så er det min overbevisning, at man forst forstår de slesvigske forhold rigtigt, når man ser dem $i$ lyset af de tanker, der ligger til grund for de lige anforte begreber.

Nordslesvig - jeg lader Sydslesvig ligge - havde omkring $1830 \mathrm{i}$ den anførte forstand en befolkning uden historie. Gennem fem hundrede år havde danskerne ikke haft en egen, kulturbærende overklasse. Al øvrighed var tysk ligesom al højere undervisning, i købstæderne også alle folkeskoler. Når der desuagtet fortsat eksisterede et dansk Nordslesvig, skyldtes det især to faktorer: 1) Der fandtes næsten ingen adel, og kun den augustenborgske hertug og hans forpagtere virkede i tysk retning. 2) Den tyske finkulturs udbredelse hæmmedes kraftigt af indflydelsen fra de områder, som i gejstlig henseende hørte til Kongeriget.

En danskorienteret slesvigsk historieskrivning var der naturligvis 
slet ikke tale om. I en tid, hvor øvrighedens historie regnedes for landets historie, blev der intet tilovers til Nordslesvig. Hvis der var blevet skrevet en Sønderjyllands historie, ville ikke ét ord $i$ afsnittet om den nyere tid have vist læseren, at befolkningens store flertal var dansk. Et dansk-slesvigsk modstykke til slesvigholstenernes statsog retshistoriske argumentation kunne i virkeligheden ikke opstilles.

De åndelige våben, den danske bevægelse kunne bruge $\mathrm{i}$ kampen mod slesvigholstenerne, måtte derfor hentes i folkesproget og almuekulturen. Den tyske romantik kom til at tjene den danske sag. Allerede i 1832 skrev Christian Paulsen om Slesvigs "Volkstümlichkeit«, og under det danske styre mellem de to slesvigske krige fik offentligheden ikke en Slesvigs historie, skrevet i dansk ånd, men Allens store anklageskrift om det danske sprogs vanrøgt i Sønderjylland. Her formulerede Allen, hvad de nationalt bevidste mente om de danske slesvigeres fortid: "Fremmedherredømme, folkeundertrykkelse, et godt og dygtigt folk snart sukkende i stilhed over den dybe uret, det måtte lide, snart opløftende klager, som ingen hørte«.

Kxrnen i det, som Allen her gav mæle i så velklingende ord, var indeholdt $\mathrm{i}$ de nordslesvigske bønders krav om afskaffelse af det tyske øvrighedssprog i 1836.

Dette krav var først og fremmest socialt og ikke nationalt. De bønder, der rejste kravet, ville hævde sig overfor embedsstanden; embedsmændene var til for folkets skyld og ikke omvendt. Under de nordslesvigske forhold måtte bøndernes sociale rejsning nødvendigvis antage en national farve; men dette var ingenlunde tilsigtet.

Hvem deltog $i$ denne bonderejsning? Langt fra alle, og slet ikke småkårsfolkene. Og de velhavende bønder, der førte an, repræsenterede kun nogle få nordslesvigske egne, forrest blandt dem Haderslev østeramt.

Det var ikke så mærkeligt, for $\mathrm{i}$ denne del af Nordslesvig var bønderne nået langt $\mathrm{i}$ borgerliggørelse, og borgerliggørelse og national bevægelse er to sider af samme sag.

Bøndernes borgerliggørelse var i Nordslesvig begyndt for længe siden, spredt og sporadisk vel allerede i slutningen af det 16 . århundrede, begunstiget af feudalismens svaghed i denne landsdel. Den egn, hvor bonden først stod helt fri, rede til en udvikling på lige fod med byernes borgere, var netop Haderslev osteramt. Her havde der i århundreder ikke været nogen adel, og her var landsbyfællesskabet 
tidligt forsvundet. Netop på denne egn kunne man dengang, altså i slutningen af det 18 . århundrede, spore de første vidnesbyrd om en patriotisk, statsbevidst indstilling. Med krigen mod England og den påfølgende stagnation blev denne udvikling standset eller $i$ hvert fald sinket. Den fornyede økonomiske fremgang efter 1830 bevirkede, at de muligheder for politisk aktivitet, som stænderforordningen gav, øjeblikkelig blev udnyttet, og hele den nordslesvigske landbefolkning sluttede op om de sprogkrav, som Nis Lorenzen førte frem i stænderne.

Bøndernes danske bevægelse var vendt mod overklassen, mod embedsmændene og deres venner, det velhavende borgerskab; og bønderne fik tilslutning fra småborgere og arbejdere, der stod i et modsætningsforhold til de samme befolkningsgrupper. En senere tids historikere, der anså de nationale modsætninger for de fundamentale, var tilbøjelige til at betragte bønderne som danske og embedsmændene som tyske. Man mente f. eks., at den konservative amtmand Johannsen i Haderslev nødvendigvis måtte være tysk, fordi han var Nis Lorenzens modstander, og Nis Lorenzen opfattedes som national foregangsmand, fordi han havde rejst sprogsagen.

I virkeligheden var der kun én sikker spire til en national holdning i den danske bevægelses første periode, og det var den næsten grænseløse hengivenhed for den enevældige konge i København og dermed en levende uvilje mod alt, hvad der ville afbryde denne forbindelse til fordel for en nærmere tilknytning til Tyskland.

Dette almueagtige og $\mathrm{i}$ virkeligheden fornationale træk: kongen som værner om de små i samfundet, bevaredes meget længe. Ikke blot Frederik VI og Christian VIII, men også Frederik VII modtoges overalt med veneration (det gjaldt også Sydslesvig), og når værftsarbejderne i Åbenrå med økser på skuldrene havde fulgt monarken til bygrænsen, og han havde takket dem med et Hils jeres koner og børn ", var det en begivenhed, hvis betydning blev indprentet både børn og børnebørn. Og for Christian IX, der havde været slesvigernes konge i mindre end et år, brændte man i mange år fødselsdagsblus i de vestslesvigske egne.

Det politiske betydningsfulde var, at der på grundlag af denne kongetroskab kunne opbygges en stærk patriotisk følelse for den danske stat, men vel at bemærke for den danske helstat lige til Elben. De danske blade i Haderslev, Ảbenrå og Flensborg var af hjertet 
unitariske, og det kunne derfor godt være svært at kende forskel på de to Haderslev-blade: den danske "Dannevirke« og det slesvig-holstenske "Lyna ". De senere amputationer, der flyttede grænsen først til Ejderen og siden til Skelbækken, accepteredes kun af hård nødvendighed af den $x$ ldre slægt.

Hvis man ved dansk nationalfølelse forstår en følelse, der omfatter mere end troskab mod det danske sprog, den danske konge og den danske stat, og sæetter tilhørighed til det danske folk i centrum, så må det indrømmes, at nordslesvigernes nationalfølelse før 1848 langt fra var fuldt udviklet. Den udbredte vrede over Hiort Lorenzens nationale aktion i stænderne i 1842 og det såkaldte sognefogedoprør i Haderslev østeramt et par år senere er vidnesbyrd herom. På Rødding højskole syntes både den utrolige Johan Wegener og hans efterfølger, den højspændte Christian Flor, at de gårdmandssønner, der var skolens elever, langt fra stod mål med deres forventninger til en nationalt vågen dansk ungdom. Det var ingenlunde sådan, som Flor mente, at nordslesvigerne blev danske, fordi deres sjal var dansk, og de derfor ikke kunne blive til andet. Han forstod ikke, at de havde lige så lidt tilovers for det kongerigske som for det slesvigholstenske bourgeoisis nationalliberale programmer.

Det, der afgjorde problemet for dem, var, at slesvigholstenerne kastede sig i armene på den tyske enhedsbevægelse og således gjorde et brud med Danmark uundgåeligt. Men dermed havde Kongerigets nationalliberale på ingen måde vundet nordslesvigerne for sig, og i krigen mod slesvigholstenerne og tyskerne spillede tanken om kongens sag en lige så stor og til at begynde med sikkert en større rolle end hensynet til den danske nations sag.

Det er værd at huske på, at Dannevirkes redaktør P. C. Koch i januar 1848 skrev til Flor: »Når jeg fortæller folk fra landet, at vi nu får en art konstitution, så bliver de alle ængstelige, som om der hændtes landet en ulykke. I dag hørte jeg, at bønderne i Fjelstrup erklærer at ville vove liv og blod for kongen, dersom nogen vil prøve på at indskrænke hans autoritet; thi noget fler-herskab vil de ikke vide om at sige. Denne idé er fremherskende overalt på landet, og jeg tror, den gennemtrænger hele den danske bondestand. Den danske bonde ser skævt til enhver uden for hans stand, og det er ham en satisfaktion, at der er en mand over dem, de må respektere lige så meget, som han gør det.« Og senere $\mathrm{i}$ samme brev: *Vi har aldrig 
villet gøre os nogen klar forestilling om, hvor dybt rodfæestet den kongelige enevoldsmagt er her i Danmark, men den er virkelig frygtelig grundfæestet, ingen magt på jorden kan rokke den, undtagen man ville mishandle bonden og borgerne eller af fri vilje nedlægge den. Christian VIII var meget yndet af bonden, men sønnen er næsten mere, og han behøver blot at vinke, så knuser bonden, hvad det skal være. «

Der er endnu et stykke af et brev fra denne tid, som jeg gerne vil have lov at citere. Det er skrevet af Hans Krüger, som i 1847 var blevet valgt til stænderdeputeret som førende $i$ en dansksindet, men tillige særslesvigsk gruppe. Denne politiske tendens må selvfølgelig haves in mente ved læsningen af det brev, som han 5 . april 1848 sendte til krigsminister Tscherning, men ikke mindre må det huskes, at han i den uge, der gik forud for brevets affattelse, havde organiseret en efterretningstjeneste $\mathrm{i}$ Nordslesvig til fordel for den danske hær. I brevet skriver han bl. a., efter først at have beklaget, at der ikke er arresteret én person af adelstanden:

»Endvidere anser vi det som en fædrelandsk pligt at gøre opmærksom på, at ligesom slesvigholstenerne har stukket sig bag den tyske nationalitets fane, dels for at vække sympatier hos det tyske folk for opnåelsen af deres forræderiske hensigter, dels for at skjule deres aristokratiske tendenser, ligeledes det nationale parti i Danmark og dets få tilhængere i Slesvig ikke har bidraget lidet til meningernes forvirring blandt folket. Det bør aldrig tabes af sigte, at Slesvigs ejendommelighed især består deri, at det danner broen mellem to nationaliteter og at det, som følge heraf, ej alene indeslutter to nationaliteter, men også så at sige en tredje, der består $i$ en national farveløshed, ja, endmere, at denne nationale farveløshed, trods al national ophidsning fra begge sider endnu mere eller mindre udgør slesvigernes særkende.« Han fortsætter, at armeen bør »afholde sig fra spørgsmålet: 'Dansk eller tysk?' og adoptere det mere passende og med hans majestæt kongens proklamation mere overensstemmende: 'Slesviger eller slesvigholstener?', 'Kongen tro eller oprører?' «. Så vil også mellem- og sydslesvigerne modtage armeen som venner.

Dette brev ville Krüger sikkert ikke have skrevet i 1850. Da havde Treårskrigen gjort tilslutningen til Danmark til en indiskutabel sag for nordslesvigerne, og denne holdning blev de yderligere bestyrket i under det påfølgende danske styre frem til 1864. 
Men dette danske styre var et reaktionært embedsmandsstyre, som med hård hånd afbrød den frodige folkelige udvikling, der havde præget »den nationale opvågnens tid «, og som forhindrede opfyldelsen af de demokratiske forhåbninger, der var spiret frem for 1848 og $i$ 1848.

Dermed forgreb styret sig på den danske bevægelses kraftkilde. Censur og polititilsyn ramte ikke tyske modsat danske, men alle oppositionelle kræfter, der kunne true den fortsat bestående enevælde. Frederik Fischer i Ảbenrå erklærede, at forskellen mellem nu og før kun var den, at redaktøren nu blev angrebet nordfra $i$ stedet for sydfra. Både han og Koch nedlagde deres redaktørposter, og folketaleren Laurids Skau blev pacificeret med et ben som amtsforvalter. Værre var det, at der ikke, som det hedder $i$ visen, var nye for de gamle, som faldt. Befolkningen, og det gjaldt især de egne, hvor det danske røre før 1848 havde været livligst, sank hen i passivitet.

Man skulle derfor have ventet, at den preussiske erobring og den målbevidste og hårdhændede afdanskning, som preusserne straks tog fat på, havde haft store chancer for at gøre det af med nordslesvigernes svækkede modstandskraft. Der var også mange kendsgerninger, som pegede $\mathrm{i}$ den retning. Først og fremmest lykkedes det de nye magthavere at gøre folkeskolen halvt tysk, uden at befolkningen gjorde kraftig modstand mod denne indgribende forandring. I de sydlige strøg og i købstæderne blev skolerne med flertallets tilslutning rent tyske. Det danske stemmetal ved valgene gik i løbet af en snes år ned til det halve. I den tyske rigsdag indskrænkede danskerne sig til en protestpolitik, der efterhånden kun appellerede til det $x$ ldre slægtled. Nationale organisationer, der søgte at sammenfatte den danske befolkning, fandtes ikke.

Forklaringen på, at det gik så dårligt og samtidig forklaringen på, at den danske sag trods alt holdt sig i live, finder man vel især $\mathrm{i}$ Pragfredens $\$ 5$, der lovede befolkningen $\mathrm{i}$ det nordlige Slesvig, at den ved en folkeafstemning måtte afgøre, om den ville tilhøre Danmark eller Tyskland.

De danske nordslesvigeres politik var indstillet på denne afstemning, hvis udfald ingen var i tvivl om. Protestpolitikken og for en del også den manglende danske aktivitet skal ses på denne baggrund. Den voldsomme udvandring fra Nordslesvig skal i stort omfang forstås ud fra den samme forudsætning. De unge ville ikke være tyske 
soldater, når de inden længe kunne regne med at skulle gøre tjeneste i den danske hær. Andre tusinder opterede af samme grund for Danmark.

På den anden side afholdt troen på en snarlig genforening med Danmark mange fra at slutte sig til tyskerne, og det samme perspektiv var ikke egnet til at styrke de tysksindede. Selv om den nordslesvigske danskhed var nok så svækket i slutningen af 1870'erne, ville ingen benægte, at Nordslesvig var dansk.

Spørgsmålet var imidlertid, om danskheden på længere sigt kunne overleve ophævelsen af $\$ 5$ og dermed udsigten til en langvarig tilværelse under tysk styre. Landråd von Rosen i Haderslev udtrykte forhåbningerne $\mathrm{i}$ tyske kredse, $\mathrm{da}$ han $\mathrm{i}$ anledning af danskernes protest mod det skete udtalte: "Det er det danske partis sidste suk ".

Værre var det, at man også i nøgterne danske kredse anså situationen for yderst alvorlig. Traktaten om ophævelsen af $\$ 5$ fik A. D. Jørgensen til at skrive nogle anonyme artikler om $"$ Den nationale stilling i Nordslesvig«, som i 1880 blev udsendt som særtryk. »Har dette land en fremtid? « spurgte han. »Det er vel umuligt at vide, hvad en kraftig, selvbevidst befolkning kan bære, hvor længe den i inderlig kærlighed til det medfødte og i ædel trods mod det pånødte kan bevare sit eget liv; det er et tidsspørgsmål med et ubestemmeligt svar; men det er dog kun et tidsspørgsmål; selv det ædleste folk består dog kun af mennesker, og det ville være overmenneskeligt her at forudsætte en uudtømmelig modstandskraft.«

$\mathrm{Nu}$ kom det som bekendt til at gå ganske anderledes; i stedet for danskhedens undergang fulgte dens uimodståelige fremgang og endelige sejr. Det er i øjeblikket umuligt at give et velfunderet svar på spørgsmålet om, hvorfor det gik således; de alsidige og indtrængende undersøgelser, der skal til, før der kan fremsættes en tilfredsstillende forklaring, har ingen foretaget endnu. Det må imidlertid være tilladt at gå ud fra, at de gængse forklaringer ikke dur. Man kan ikke tro, at det var nok til at vende strømmen, at taktikken blev lagt om ved edsnægteriets opgivelse eller, som Mackeprang skriver, at edskampen havde rusket befolkningen op af dens sløvhed.

Så vidt jeg kan se, skal man søge den dybeste, men naturligvis ikke den eneste forudsætning for det danske opsving, der indledes i løbet af 1880'erne, i de indgribende forandringer, der fandt sted på det økonomiske og sociale område, og som kan betegnes som den tredje 
og afgørende etape på gårdmandsstandens vej henimod en fuldt borgerlig eksistens. Den første etape placerer jeg i slutningen af det 18. århundrede, den anden i tiàret før 1848, og hver gang mener jeg at kunne konstatere en tydelig parallellisme mellem borgerliggørelse og national udvikling.

Befolkningsudviklingen efter 1864 styrkede $\mathrm{i}$ høj grad gårdmandsstandens i forvejen dominerende stilling i Nordslesvig. Udvandringen fjernede størsteparten af de mange vestslesvigske småkårsfolk, der kunne have udviklet sig til en social urosfaktor, og stagnationen $i$ byerhvervene bevirkede samtidig, at der ikke opstod en socialdemokratisk arbejderklasse af betydning.

Som følge heraf reduceredes de sociale forskelle i Nordslesvig, og da gårdmandsstanden beherskede landsdelens politiske liv, kunne de danske organisationer i vigtige spørgsmål præsentere Nordslesvig som en sluttet blok. Ikke med urette har man $\mathrm{i}$ årene for verdenskrigen talt om »Bonderepublikken Nordslesvig".

Gårdmandsstandens tyngdepunkt lå nu i Sundeved og på Als, dvs. i de egne, hvorfra udvandringen havde varet mindst, og som derfor også havde lidt mindst under det store tab af kapital, der havde været en af udvandringens negative følger. Her havde man derfor i ly af den tyske agrarbeskyttelse kunnet gå i spidsen for landbrugets omlægning til kapitalkrævende intensiv drift. Når man samtidig holder sig for øje, at de vestlige egnes landbrug kun fulgte langsomt efter $\mathrm{i}$ denne modernisering, er det nærliggende at postulere en sammenhæng mellem dette forhold på den ene side og på den anden side den kendsgerning, at edsaflæggerpolitikkens forkæmpere, Hans Lassen og H. P. Hanssen, var hjemmehørende $\mathrm{i}$ gårdejerkredse $\mathrm{i}$ netop Als og Sundeved og havde deres trofasteste tilhængere her.

Med omlægningen af landbruget var forenet en selvstændiggørelse af bønderne, et ønske om at klare de økonomiske problemer selv, uden bistand fra myndighederne eller byernes borgere. Resultatet blev, ligesom i Kongeriget, opbygningen af et net af landbrugsorganisationer og -foretagender: landboforeninger, andelsmejerier osv. Forbilledet var landbruget i Danmark, der nu afløste Holsten og Angel i denne egenskab.

Man kunne måske have tænkt sig, at omlægningen af det nordslesvigske landbrug godt kunne være foregået i nøje tilknytning til forholdene i Tyskland. Det forhindredes imidlertid af en rakke faktorer, 
af hvilke der er grund til at fremhæve, at det tyske styre ikke ville tolerere de nordslesvigske bønders økonomiske selvstændighed, som det med rette betragtede som den klippe, hvorpå danskhedens politiske modstandskraft hvilede. Det varede længe, før danskerne blev klar over denne sammenhxng mellem økonomi og politik, men de tyske myndigheder gjorde fra et tidligt tidspunkt »kampen om jorden * til den tap, hvorom den nationale kamp mere og mere kom til at dreje sig.

Til at begynde med troede de preussiske myndigheder, at de kunne vinde den svækkede danske befolkning gennem et dansk-tysk samarbejde på det økonomiske område. I $1878 \mathrm{skrev}$ regeringspræsident Bötticher $\mathrm{i}$ en indberetning til Berlin: "Jo mere den overbevisning vinder indpas, at et samvirke med befolkningens tysksindede elementer og med statens myndigheder på de materielle interessers område er en nødvendighed, og der som følge heraf skabes talrige berøringspunkter mellem partierne, desto mere vil også de fronderende indbyggere $\mathrm{i}$ det nordlige blive klar over fordelene ved forbindelsen mellem Deres majestæts stater, og desto utaknemmeligere bliver operationsområdet for den statsfjendtlige agitation «.

National neutralitet på det økonomiske område, altså f. eks. i landboforeninger og sparekasser, kunne imidlertid kun opnås, hvis den preussiske stat fik indrømmet en mxglende eller kontrollerende myndighed, og noget sådant var bønderne selvfølgelig ikke til sinds at tilstå en så fjendtlig magt. Da denne omvej ikke førte til målet, måtte den preussiske stat blotte sin kløer og sætte sine magtmidler direkte ind mod danskernes økonomiske positioner. Det fortjener at fremhæves, at mens den politiske kurs overfor danskerne helt op til verdenskrigen svingede i overensstemmelse med uden- og indenrigspolitiske konjunkturer, så skærpedes det økonomiske angreb mere og mere og nåede et højdepunkt umiddelbart før verdenskrigen, da tyske kolonister blev bosat for statens penge, medens kreditforeningerne af regeringen fik pålæg om at nægte danskerne lån.

Under de givne forhold måtte denne desperate politik nødvendigvis slå fejl. Kampen om jorden styrkede kun sammenholdet $\mathrm{i}$ den danske lejr, der var i stadig materiel fremgang, og den øgede ønsket om en adskillelse fra Tyskland. Navnlig ungdommen meldte sig til de danske faner, og den ønskede skarpe standpunkter. I tyske embedsmandskredse var man godt klar over, hvor udviklingen bar hen. Landråd 
von Tschirschnitz i Sønderborg, der havde dette embede fra 1879 til 1912, skrev i $1908 \mathrm{i}$ en fortrolig indberetning, wdass die deutsche Jugend, das heranwachsende Geschlecht, auf das wir gehofft hatten, männlich und weiblich ins dänische Lager hinüberzieht. Wir haben politisch jahrzehntelange Arbeit unwiderbringlich verloren; das Vertrauen ist verschwunden, der Mut ist weg und die Hoffnung ist verloren. «

Til det moderne, markedsproducerende og kapitalkrævende nordslesvigske landbrug med dets bevidst danske organisationer svarede et net af foreninger til værn for danske politiske og kulturelle interesser. I modsæetning til, hvad der havde været tilfældet i de første 25 år efter 1864, havde de en meget stor og en meget aktiv medlemskreds, og ånden i dem var, ligesom i de okonomiske organisationer, ikke blot bevidst dansk, men klart demokratisk. Folkelighed og demokrati var begreber, der var synonymer med danskhed, mens tyskhed blev forbundet med begreber som magtbegxr, hovmod over for andre folkeslag og underdanighed over for egne ledere. Det hørte med til den nye nordslesvigske danskheds væsen, at den optog visse internationalistiske træk: den nationale kamp tilsigtede ikke blot en tilbagevenden til Danmark, men rummede tillige et forsvar for de demokratiske værdier, man havde tilegnet sig, i forbund med andre nationale mindretal, der var i samme situation som nordslesvigerne, og med den antiautoritære opposition i Tyskland, navnlig det frisindede parti og socialdemokraterne.

Disse momenter af internationalisme og af vilje til samarbejde med venstrekredse begrænsedes dog af de nordslesvigske gårdejeres horisont. De var ikke i tvivl om, at de var befolkningens kxrne, og at danskheden stod og faldt med dem. Udviklingen $\mathrm{i}$ byerne opfattede man som noget andenrangs. Man lod sig derfor med god grund ikke gå på af den danske tilbagegang $\mathrm{i}$ de nordslesvigske byer, men anvendt på Flensborg førte denne indstilling til et afgørende nederlag. Den joviale Gustav Johannsen kunne ganske vist fastholde de flensborgske småborgere, men de flensborgske arbejderes overgang til socialdemokratiet stod den danske ledelse fuldstændig rådvild over for, og navnlig H. P. j-Tanssen og hans slægtled synes ikke at have forstået, hvor meget der her stod på spil. Den højreekstremistiske Jens Jessen kunne formodentlig ikke have været dårligere placeret, end han var det $\mathrm{i}$ Flensborg, og storbondesønnen H. P. Hanssen har vel på forhånd 
anset Flensborg for en tabt by. Ingen af dem havde noget at sige til socialdemokratiske arbejdere.

Mellem H. P. Hanssen og Jens Jessen rådede der som bekendt en dyb modsætning. Jessen nærede personlig antipati mod H. P. Hanssen, men modsætningen har også en almen interessant side, idet den viser os kløften mellem to generationers danskhedsfølelse. For Jens Jessen var Danmark som det gamle, uforglemmelige fædreland det altafgørende. H. P. Hanssen betonede derimod i første rxkke den nordslesvigske befolknings danske nationalitet.

I 1888 havde H.P. Hanssen i serien Studentersamfundets småskrifter udsendt pjecen "Sønderjyderne under fremmedherredømmet $\ll$. Pjecens hovedstykke udgøres af en historisk redegørelse for udviklingen i Nordslesvig efter 1864. Det unge Nordslesvigs grundsynspunkter kommer til udtryk $\mathrm{i}$ indledningen.

Der står her: "Da den franske julirevolutions efterdønninger gik ud over Europa, overalt kaldende friheds- og nationalitetsbevægelser til live, sporedes virkningerne også i Sønderjylland. Der blev slået til lyd for modersmålets ret, og folket rejste sig efter slægtaldres dvale til kamp mod tyskens overgreb... Embedsstanden og godsejerne var tyske, og kun et lille mindretal af borgere turde $\mathrm{i}$ førstningen slutte sig til den danske opposition, i hvis rækker bønderne længe stod så godt som ene. Derved fik den et demokratisk præg, og støttet af frihedsbevægelsen i Kongeriget voksede den sig efterhånden sammen med den, mens enevoldskongen og hans regering fremmede udviklingen af slesvigholstenismen, der førte til katastrofen i 1848 og den derpå følgende Treårskrig «. Men efter denne krig, hedder det videre, "kom en ny godsejerstand ind $i$ landet, og borgere og bønder trådte snart i baggrunden. $*$

Skriftet fremkaldte den voldsomste harme hos Jens Jessen og hans meningsfæller, men først i 1890 tog han heftigt til genmæle mod det. Han imødegik da udførligt H. P. Hanssens negative vurdering af godsejere og embedsmænd og vendte sig forbitret imod, at "hans majestæt betegnes som den danske konge " (og ikke som Christian IX). Den danske bevægelse i Sønderjylland - påstod Jessen - whar aldrig været demokratisk $\mathrm{i}$ moderne forstand. Tværtimod har streng loyalitet og kongetroskab været et stærkt moment i den «. Han kunne selvfølgelig heller ikke acceptere, at danskheden i Sønderjylland skulle være, som han skrev, "en affødning af den franske julirevolution «. 
Selv $\mathrm{i}$ vore dage har Jens Jessen som politiker sine beundrere $\mathrm{i}$ Nordslesvig, men jeg tror, at de fleste af dem hører hjemme i de afsides egne, hvor fortidens nøjsomhed og fortidens selvforsynende landbrug endnu levede i 1914 og var idealet lige til 2. verdenskrig. På disse kanter var de danskbevidstes problem ikke de relativt få tysksindede, men det store antal "blakkede", dvs. folk, der først og fremmest følte sig knyttet til deres dansktalende hjemstavn med dens danske fortid, mens tilhørighed til det danske folk var et tomt begreb for dem og bibelens ord om at vare ovrigheden underdanig et afgørende bud. Sådan var tilstanden $i$ hvert fald i den del af midtlandet, der ikke hørte til Tørninglen. Den indsiptsfulde nordslesvigske historiker Hans Hejselbjerg Paulsen har sikkert ret, når han siger, at $\mathrm{i}$ disse egne gav Jens Jessens tale genlyd $\mathrm{i}$ mange sind og rejste en vælgerskare, som ellers næppe var kommet på benene.

Det må imidlertid billigt betvivles, at mændene af den gamle skole kunne have skabt og bevaret et dansk Nordslesvig. Det var kun muligt, fordi den danske bevægelse i sine to store perioder, før 1848 og efter 1880 , gav udtryk for tidens progressive bestræbelser og ikke kun var en national bevægelse i snæver forstand.

På det danske årsmøde i 1913 udtrykte H. P. Hanssen noget af den samme tanke med folgende ord: "Vi er $\mathrm{i}$ pagt med livets lyse magter, vi har idealer, som vi omfatter med varme og begejstring. Derfor har vi også missionerende evne. Derfor udøver vi tiltrækningskraft. Vi opsuger ikke blot befolkningstilvæksten, men vinder også i stigende grad hjemmetyskerne... Mangt og meget $i$ de fremmedes sæd og skik, i den preussiske voldspolitik, frastøder dem «.

Med det, jeg har sagt, håber jeg tilstrækkeligt at have gendrevet den opfattelse, at den danske og den tyske bevægelse i Sønderjylland er to sider af samme sag. Min hypotese: at den danske bevægelse $i$ Nordslesvig i hovedsagen udvikler sig på grundlag af landbrugets gradvise overgang til den borgerlige okonomi, stiller jeg naturligvis til debat. 